\title{
Characteristics and Development Report for the MC3714 Thermal Battery
}

\author{
Gregory L. Scharrer and Frank P. Lasky \\ Battery Development Division \\ Sandia National Laboratories \\ Albuquerque, NM 87185)
}

\begin{abstract}
This report describes the design intent, design considerations, system use, development, product characteristics, and early production history of the MC,3714 Thermal Battery. This battery has a required operating life of $146 \mathrm{~s}$ above $24.0 \mathrm{~V}$ with a constant current load of $0.5 \mathrm{~A}$. It is activated when the MC3830 Actuator initiates the WW42C1 Percussion Primer in the battery. 'The MC3714 employs the Li(Si)/ $\mathrm{LiCl}-\mathrm{KCl} /$ lithiated $\mathrm{FeS}$, electrochemical system. The battery is a hermeticaliy sealed right-circular cylinder with an antirotation ring brazed to the base of the cylinder. 'The battery is $50 \mathrm{~mm}$ long and $38.1 \mathrm{~mm}$ in diameter. The mass of the battery is $165 \mathrm{~g}$. The hat tery was designed and developed to provide the power for the W 82 J'TA Telemetry System.
\end{abstract}




\section{Acknowledgments}

The authors gratefully acknowledge the contributions of the following people, without whom the MC3714 could not have been developed:

Bob Wehrle (ret.) and Bob Clark, Division 2522, for technical advice ana encouragement.

Leroy Brace, Division 2526, and Carlos Herrera, Ewing 'Technology, for testing support.

Art Andazola, Division 2522-1, for fabrication of piece parts.

Don Hardy and Dave Jacobs, GEND, for technical input and production preparation activities.

Special appreciation must be given to Charlie Jones, GEND, for his outstanding work on the design, fabrication and maintenance of the GEND spin tester. 


\section{Contents}

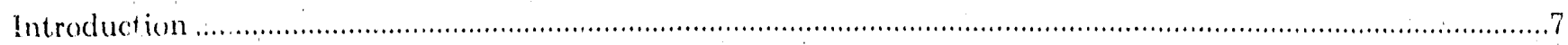

Design Intent

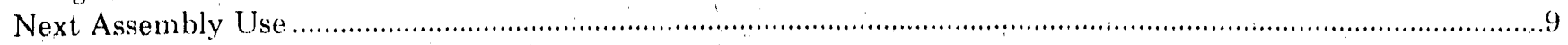

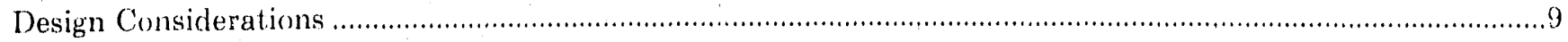

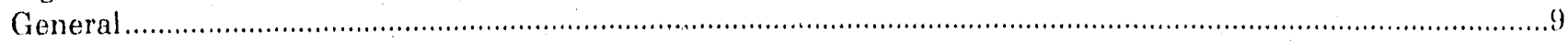

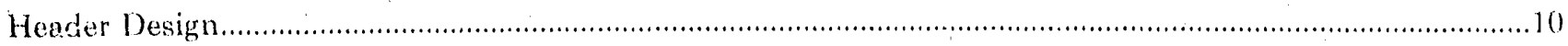

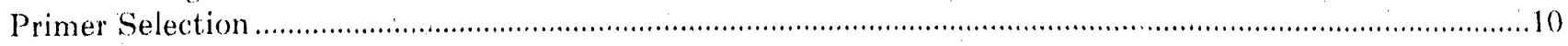

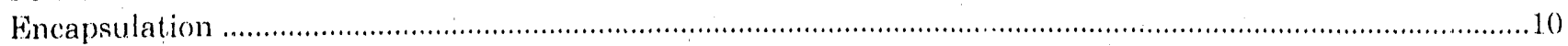

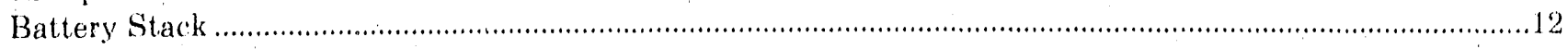

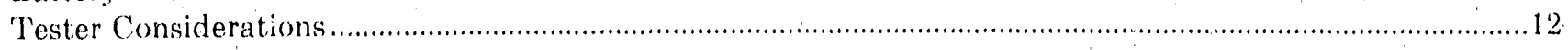

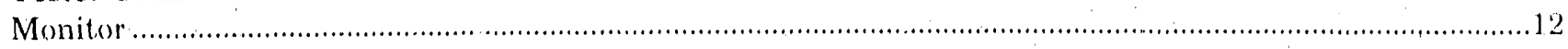

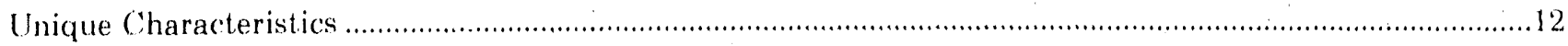

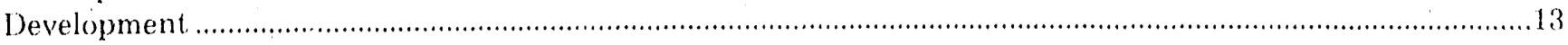

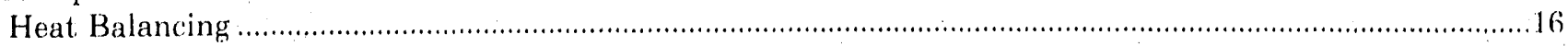

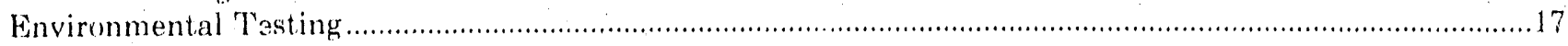

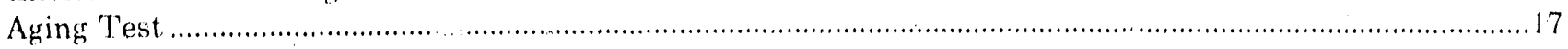

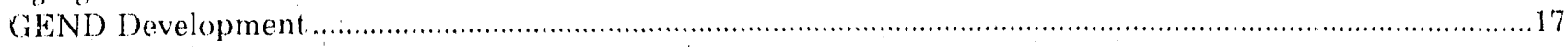

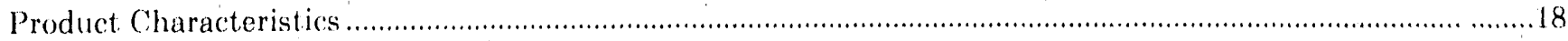

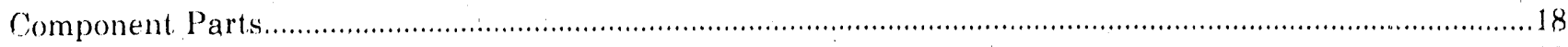

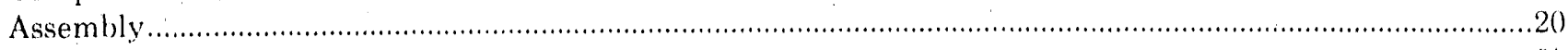

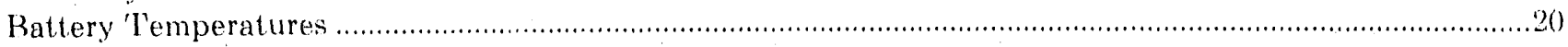

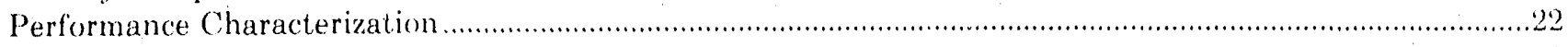

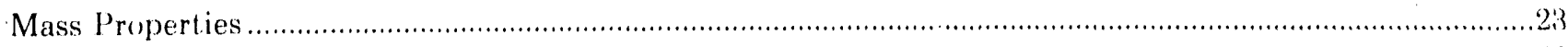

Production History …. ……

lot 1 Design Change

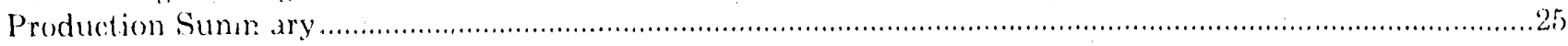

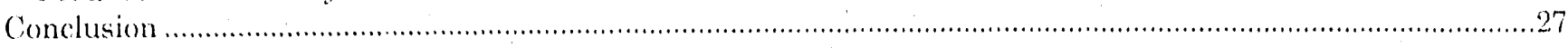

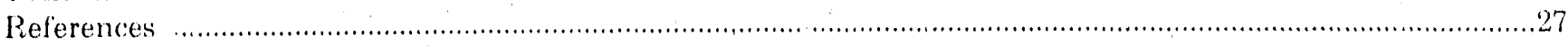

\section{Figures}

1 Cutaway View of the M(:3714

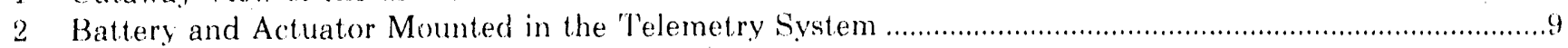

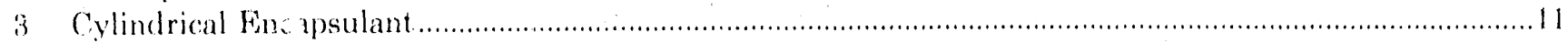

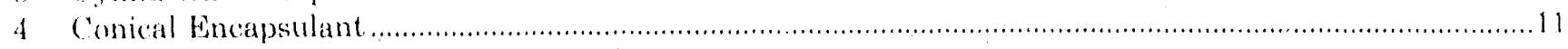

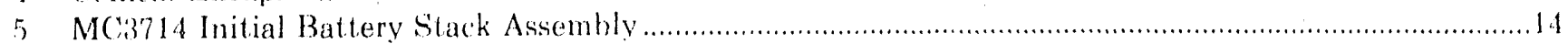

6 Stack With Separation of Double Heat Pellets...........................................................................

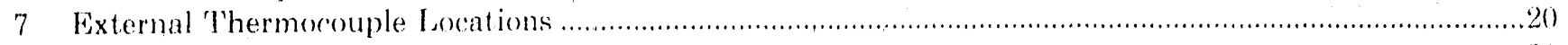

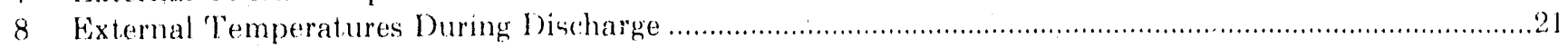

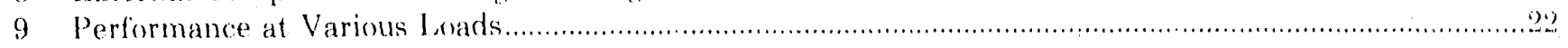

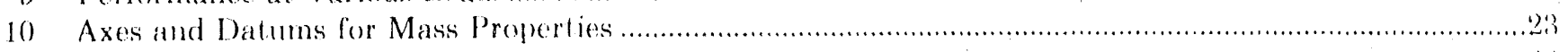

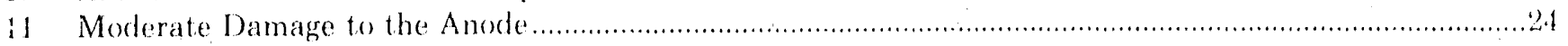

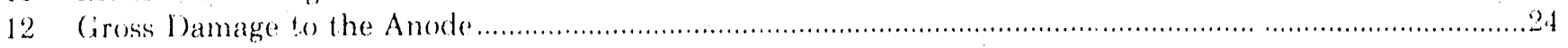

\section{Tables}

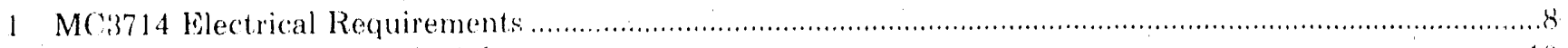

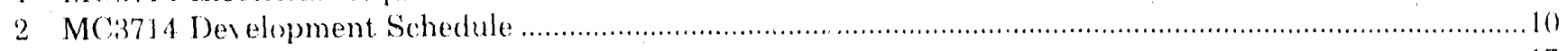

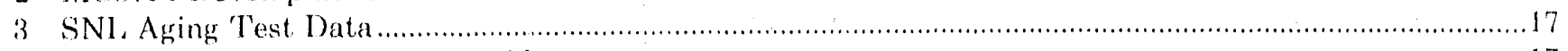

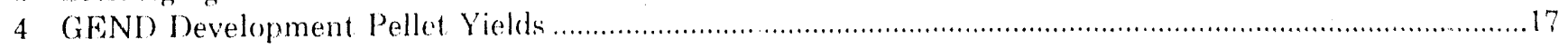




\section{Tables (continued)}

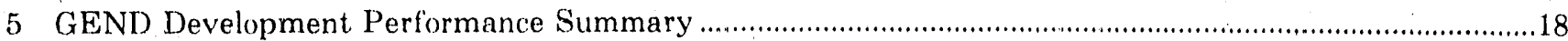

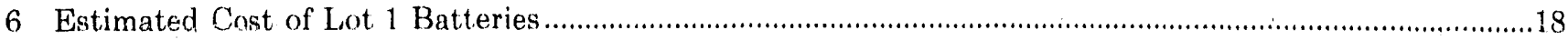

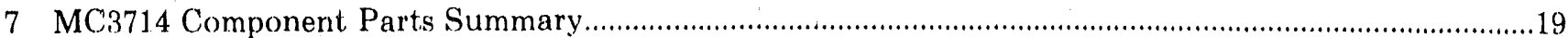

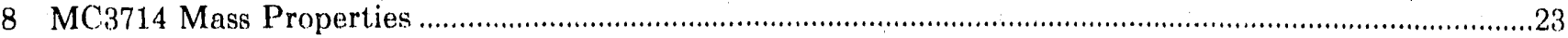

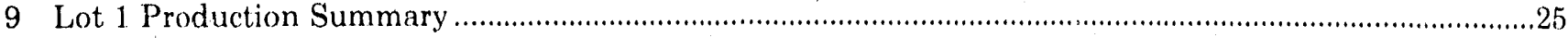

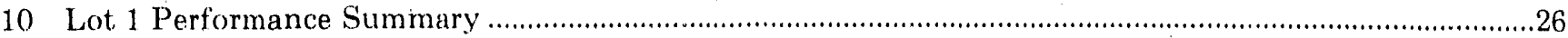

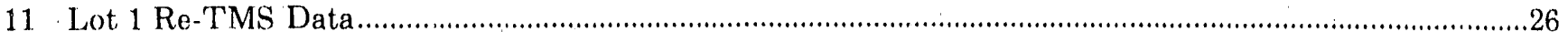




\section{Characteristics and Development Report for the MC3714 Thermal Battery}

\section{Introduction}

The MC3714, part number 318936 (Figure 1), is a mechanically activated thermal battery for the W82 Telemetry System.

The task of developing the MC8714 was assigned by Bob Wehrle, Division 2522, to Greg Scharrer and Frank Lasky of Division 2522. The GEND development engineer was Dave Jacobs, and Don Hardy was the GEND product engineer. Larry Humphries, Divi sion 8141, was the systems organization contact and was responsible for writing the interface control document. (CD239294). Ed Paboucek and Howard Devaney, both of Division 2542, designed the MC:3830 Actuator ${ }^{1}$ that attaches onto the battery. Reuben Weinmaster and Nick Durand, both of Division 2512 , were responsible for the WW'42C1 Primer ${ }^{2}$ that activates the battery.

A brief overview of the principles of thermal battery operation is presented below for the benefit of those who are unfamiliar with thermal batteries.

A thermal battery is a thermally activated primary battery that contains a fused-salt electrolyte (LiCl-KCl eutectic in the MC.3714) and an ignitable heat source $\left(\mathrm{Fe} / \mathrm{KClO}_{4}\right)$. The MC3714 thermal battery uses the $\mathrm{Li}(\mathrm{Si}) / \mathrm{l}$ iCl-KCl/lithiated $\mathrm{FeS}_{2}$ electro- chemical system." There are 16 active cells in the MC3714. Fach cell is comprised of a stainless-steel anode collector, Li anode, electrolyte bearing separator lithiated FeS cathode with Grafoil backing and an iron-potassium perchlorate heat source. The Grafoil backing serves as the cathode current collec. ior. An excess of iron in the heat source provides intercell comnection. The heat source and the active cell comporients are formed by hydraulically pressing appropriate powders into thin wafers, commonly called "pellets."

Battery ignition is achieved by a mechanical input to the WW42C1 primer in the battery. The primer cuiput is directed down the center-hole into the battery. That output ignites the heat pollets throughout the battery pellet stack. 'The heat released from the heat pellets raises the battery temperature to approximately $550^{\circ} \mathrm{C}$ within one-half second.

At temperatures above $352^{\circ} \mathrm{C}$, the solid, electrochemically iriactive electrolyte becones molten, with good ion transpurt capability. This permits the ionic transfer necessary to complete the electrochemical circuit. Unless the anode and/or cathode aro depleted, the electrockemical reaction will proceed as long as the electrolyte remains above its melting point.

A roore complete discussion of thermal battery operation is given ip Reference 4 . 


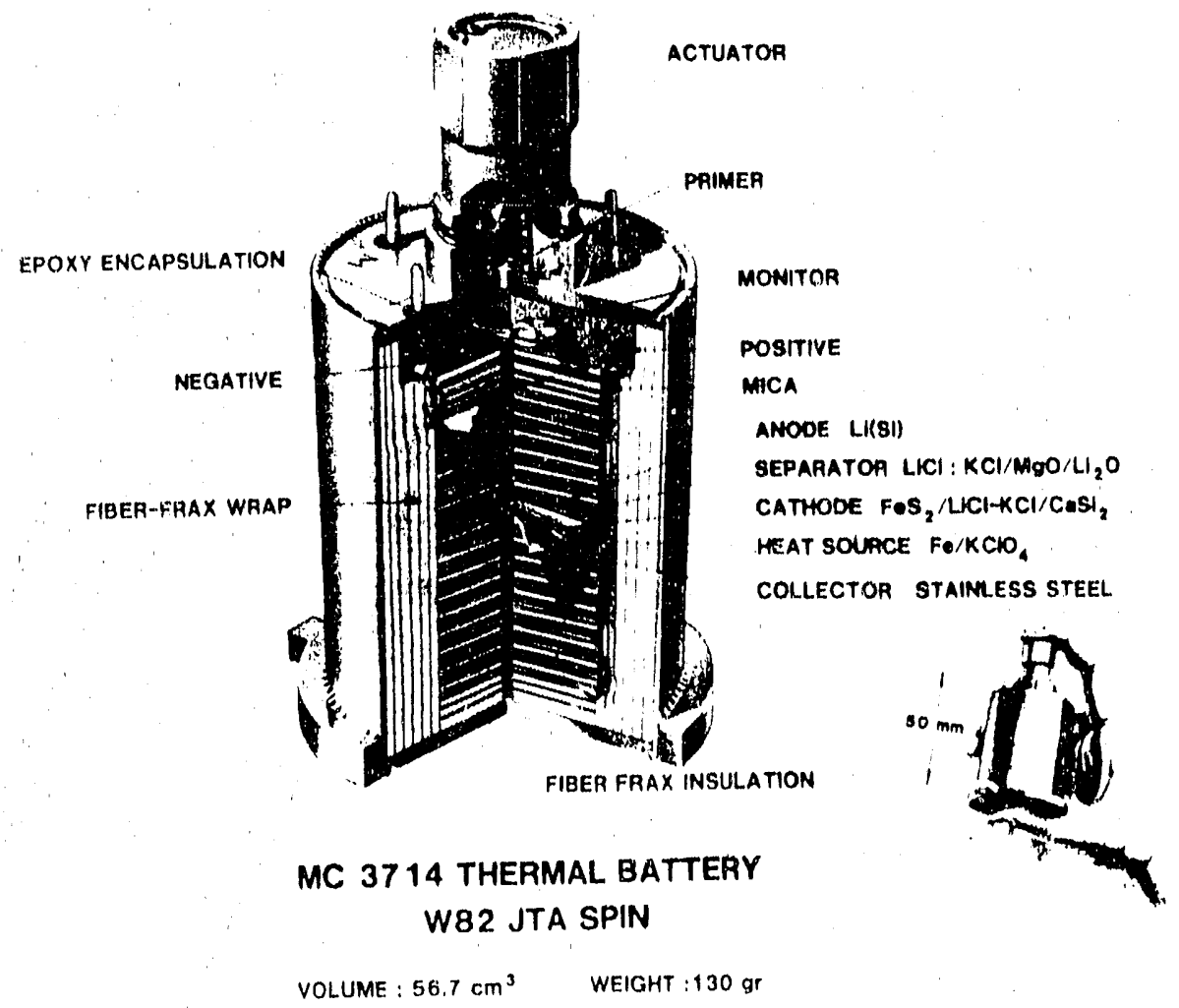

Figure 1. Cutaway View of the M(::3714

\section{Design Intent}

1. Activation. The MC8714 is activated by the M(63830 Actuator. 'This actuator initiates the WW42C1 Percussion Primer in the battery header.

2. Voltage Rise. 'The electrical potential must reach $24.0 \mathrm{~V}$ within 0.5 s after activation.

3. Voltage Regulation. 'The output voltage musl remain between 24.0 and $32.0 \mathrm{~V}$ while being discharged through a $0.5(0)-A$ constant cur rent load.

4. Activated Life. 'The voltage regulation must be maintained for at least $146 \mathrm{~s}$.

i. Temperature. 'The M(3714 must function over the temperature range of $\cdots 40^{\circ}(!$ to $54^{\circ} \mathrm{C}$.
6. Reliability. 'The probability that the MC3714 will provide the required output must be at. least 0.997 .

7. The design goal for the MC3714 storage life is 25 years.

The MC,3714 requirements are summarized in 'Table 1.

\section{Table 1. MC3714 Electrical Requirements}

Voltage rise to $24.0 \mathrm{~V}$

Maximum voltage

Voltage at required life

'Time above $24.0 \mathrm{~V}$

land
$500 \mathrm{~ms}$

$32.0 \mathrm{~V}$

$24.0 \mathrm{~V}$

$146 \mathrm{~s}$

$0.500 \mathrm{~A}$ 


\section{Next Assembly Use}

'The MC.3714 is mated to the MC:38:30 to become the battery and actuator assembly (Part No. 239294). The MCi3830 screws into the boss on the MC3714 header. A right-hand thread is used so the actuator twists in insteal of out when the W82 starts spinning. In addition, a bead of epoxy is placed on the last two threads of the actuator before it is screwed into the battery header. This ensures the actuator will stay in place through all the assembly, transportation, and functional enviromments of the telemetry system.

The battery and actuator assembly are mounted in the next assembly, as shown in Figure 2. 'The battery is on the centerline of the artillery shell. 'The battery and actuator assembly (Part No. 239294) are mounted in the back end of the telemetry assembly. A silicone rubber sleeve is fitted over the battery to protect the telemetry components from the battery heat. The electrical Jeads are soldered onto the battery terminals and the wires are potted in place.
When the artillery shell is fired, the high acceler. ation unlocks the firing pin in the MC.3830 and drives it into the WW42C1 Primer in the header. 'This initiates the primer. 'The primer output activates the battery.

\section{Design Considerations}

\section{General}

'The principal consideration was the effect of' the high $(18,000 \mathrm{rpm})$ spin rate on the battery. The cell diameter was kept as small as possible to minimize the centrifigal force on the molten electrolyte. In addition, the power leads were isolated from the stack as much as possible to prevent cells from shorting to the learls (this would occur if electrolyte leaked through the insulation and touched the leads).

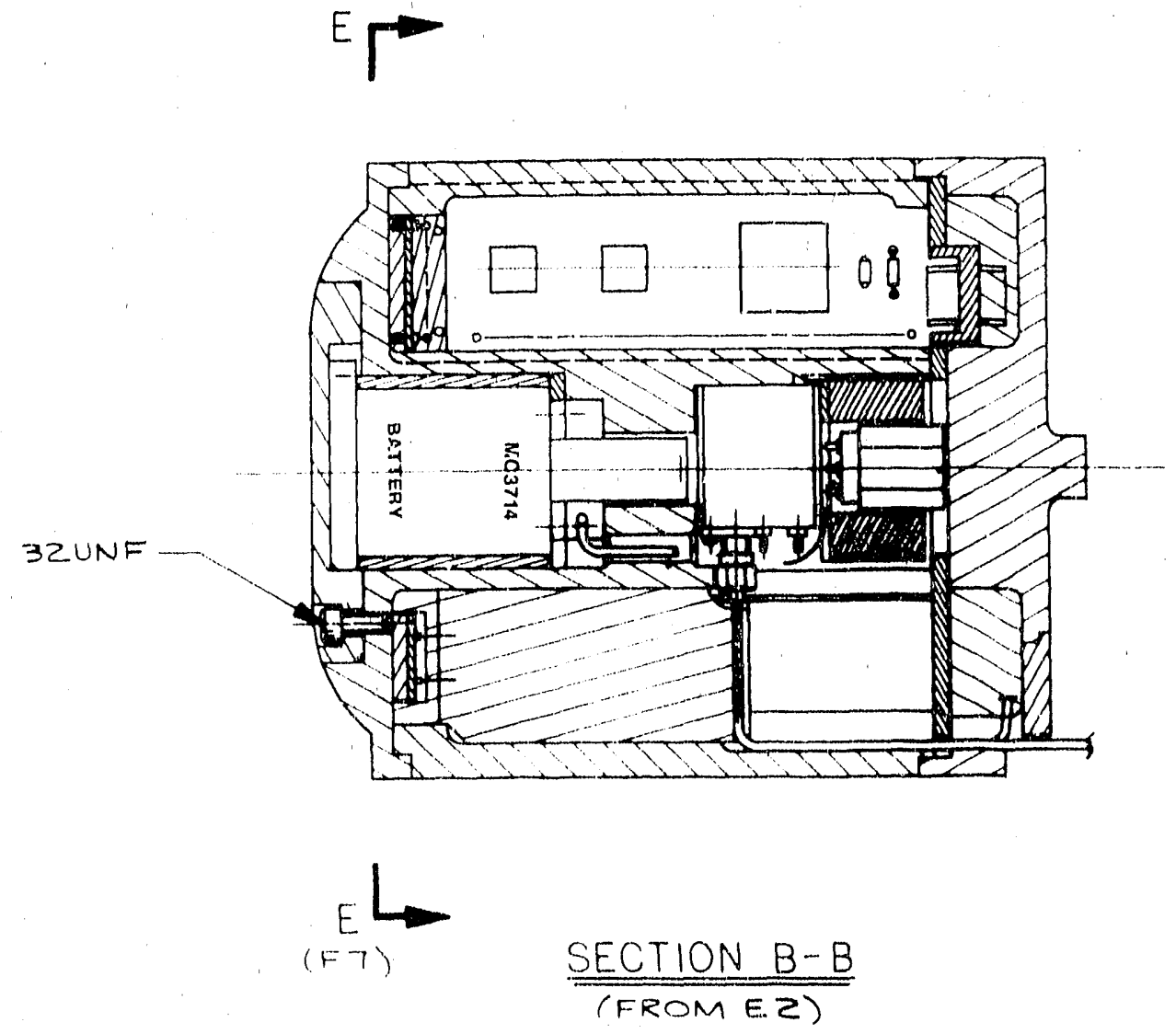

Figure 2. Battery and Actuator Mounted in the 'Telemetry System 
The high spin dictated the type of wrapping insulation used in the battery. 'l'here was room to put a $\mathrm{Min}-\mathrm{K}^{(i)}$ sleeve around the battery, but the high centrifugal force pulverized this material. Fiberfrax" insulation was used hecause it could survive the environment and adequately insulate the hattery.

A standard thin-cell separator (fic)" electrolyte/ 40) binder) was used. No modifications to the binder content or the pellet geomelry were needed to kecp) the molten electrolyte from being thrown out of the cell.

The battery program schedule is shown in Table: 2.

Table 2. MC3714 Development Schedule

\begin{tabular}{lr}
\multicolumn{1}{c}{ Event } & Date \\
\hline Conceptual Design Review & $11 / 85$ \\
Long Lead Advanced Engineer/ & $4 / 86$ \\
Release (AER) & \\
Prototype Design Review & $7 / 86$ \\
AFR & $9 / 86$ \\
Producibility Design Review & $6 / 88$ \\
Complete Fnginecring Release (C'ER) & $6 / 88$ \\
Preproduction Start & $9 / 88$ \\
Production Start & $10 / 88$ \\
Tool-Made Sample ('TMS) & $10 / 88$ \\
Re-TMS T'esting & $12 / 88$ \\
Qualification Evaluation Release ((QER) & $1 / 89$ \\
Production Complete & $1 / 89$ \\
First Production Unit (FPU) & $1 / 89$
\end{tabular}

\section{Header Design}

The M(3714 header had to have two features that most battery headers cho not have. First, it had to have a very tight tolerance (diameter tolerance: $+0.000(0),-0.0005 \mathrm{in}$.$) pocket to hold the primer- no$ other primer-activated thermal battery has the primer housed in the header. Second, it had to provide a mechanical mounting point for another component (the MCi3830). The meshanical momting feature was designed early in the program. It was decided that the Mo "3830 would serew into a threaded boss on the header. An O-ring is placed in a groove at the bottom of the boss to keep contaminants out of the firing pin-primer interface. 'The primer pocket is the standard size for the WW42(1) Primer.
The header alas has an angled grocive on the boftom side to keep the encapsulation from separating from the header during the sethack acceleration $(16,000) \mathrm{g}, 10 \mathrm{~ms})$. 'l'esting on an air gun $(16,000) \mathrm{g}$, 1 ins) showed that the encapsulation could break away from the header and cause a hattery failure by breaking the power leads. 'The addition of the angled groove encures that the potting will not break away from the header. 'The groove is similar to the one used on the M(:30)77 'Thermal Batlery."

\section{Primer Selection}

'The WW42C.1 Primer was selected for use because it was the only primer available that could ignite the entire battery stack through the centerhole. Cenerally, one of two primers is used in thermal batteries a low-temperature primer the WW42('1, which replaced the $\mathrm{M} 42(\mathrm{i})$ or a high-temperature primer (the (i]f, which replaced the $44(\$ 16)$. The high-temperature primer is used on batteries that are exposed to temperatures above $70^{\circ} \mathrm{C}$. All other bat teries use the low-temperature primer.

Fortunately, the WW42C:1 has a much more energetic and comsistent output than its predecessor, the M42G. 'The M420 could not consistently ignite the entire battery stack through the center-hole. 'The slower activation method using fuse strips (fuse strips are placed on the perimeter of the stack) would have been used if the WW42('1 had not been developed, and the MC:3714 would have had trouble meeting its rise time requirement. The WW $T 2 \mathrm{C} 1$ was not developed specifically for the MC:3714. However, the WW4:C 1 was available and appropriate for this application and the M( 3714 header needed minor mod. ifications only to incorporato it.

\section{Encapsulation}

Normally, the battery terminals are located on a bolt circle that is smaller than the cell cliameter. 'This allows a cylindrical shaped encapsulant to hold the power leads and provide the stacking surface for the cell components. 'T'his geometry is shown in Figure ?3. However, the presence of the threaded boss on the hender forced the torminals to be lorated on a rola. tively large bolt circle. A conichl shaped encapsulant. was lised so the power leads could be encased and the stacking surface could still be the same diameter as the pollets. 'This geometry is shown in Figure 4. 


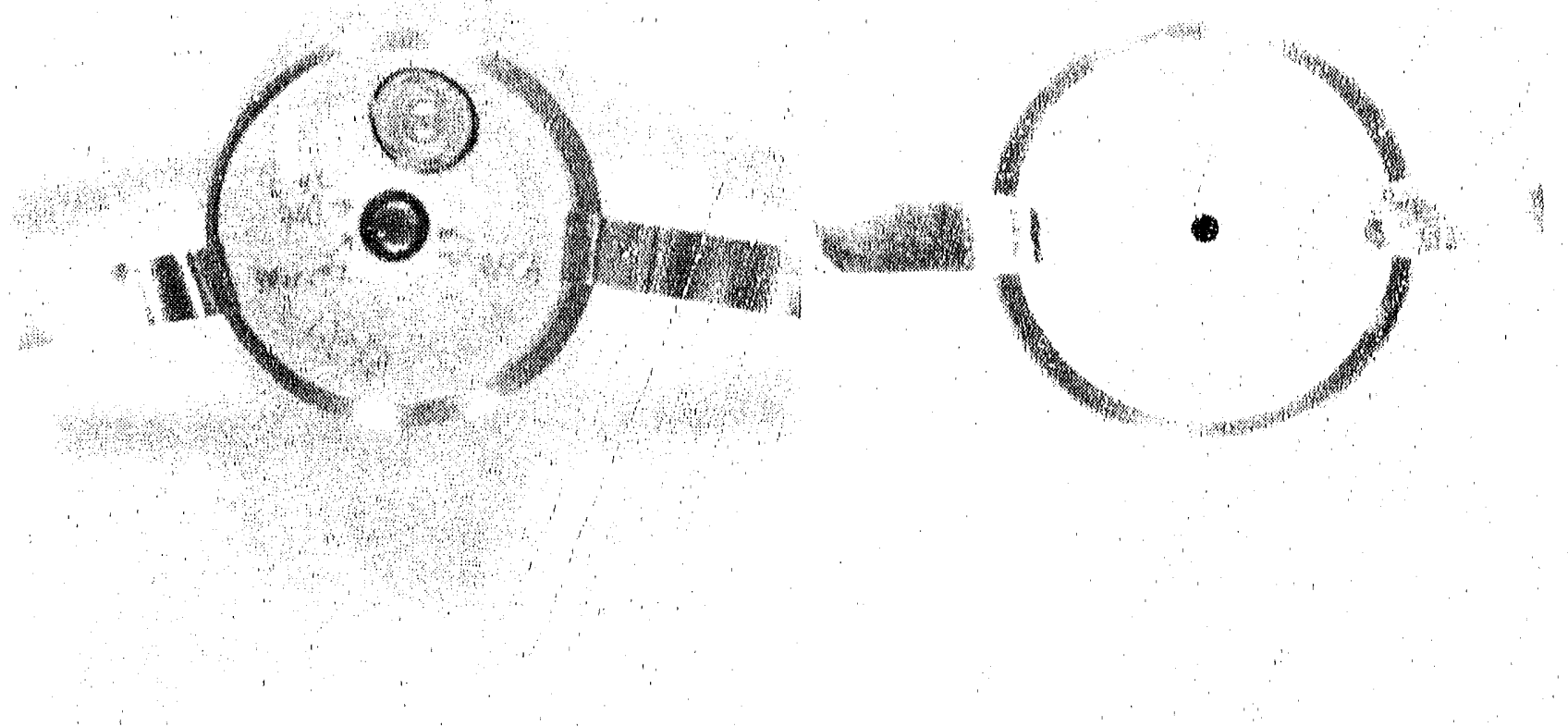

Figure 3. ('ylindrical Encapsulant

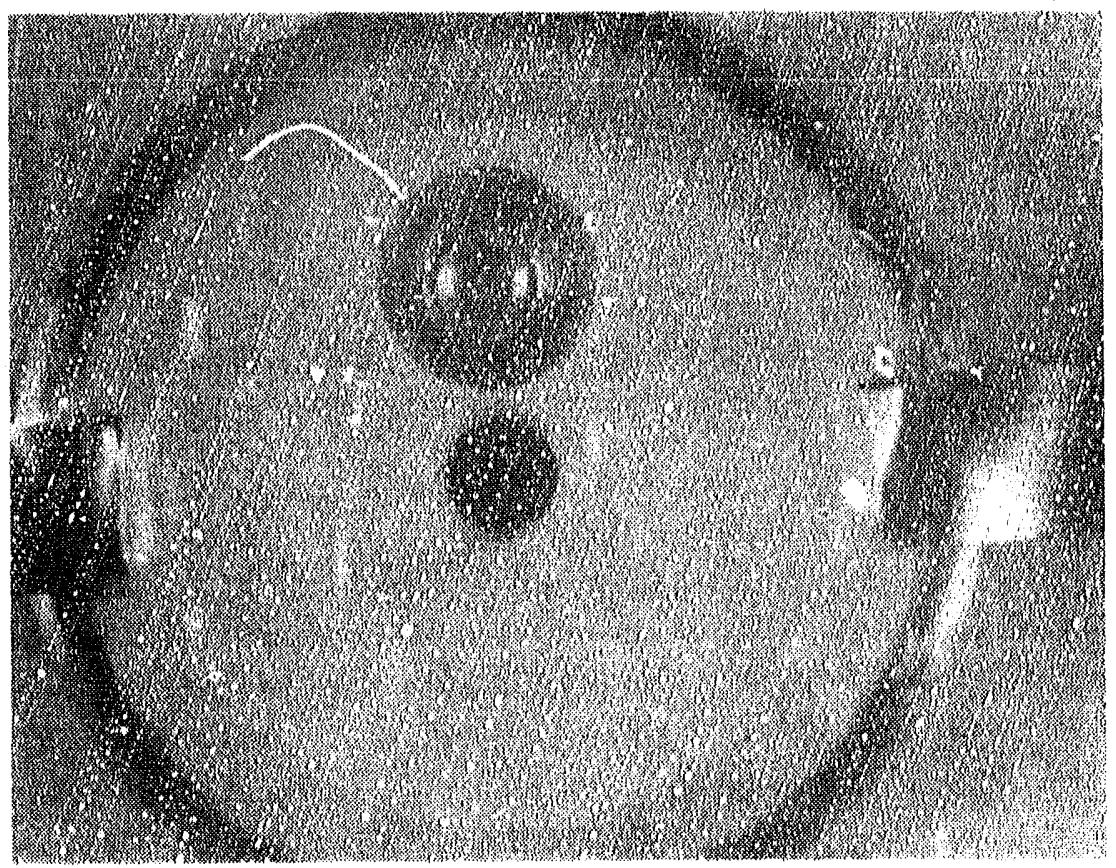

Figure 4. Conical Fencapsulant 


\section{Battery Stack}

'The battery contains 16 artive cells-the greatest. number that could be used without exceeding the $32-\mathrm{V}$ limit. A lithiated cathode was used to prevent. the occurrence of a voltage transient in excess of $32 \mathrm{~V}$. At the header end, a heat pellet is offiset from the encapsulation by a small Fiberfrax insulator. The purpose of this heat pellet is to cause the thermal monitor to open. 'The ends of the stack were otherwise symmetrical until the lot 1 design charge.

\section{Tester Considerations}

'The background load of the tolemetry system is a maximum of $400 \mathrm{~mA}$, and there are pulse loads adding not more than $100 \mathrm{~mA}$ to the battery load. This load was consolidated into a $5(1)-\mathrm{mA}$ requirement to simplify testing.

\section{Monitor}

'The T'exas Instruments AB'T'R 'Thermostatic: Switch is used to indicate the state of the hattery (i.e., fired or unfired). This switch has a reliability requirement separate from the baltery function because it cannot meet the battery reliability requirement $(0.937)$. 'The switch reliability requirement is 0.95 .

'The monitor has functioned very reliably in this battery. There was one failure (at low temperature) in development and none in production. One reason for this unusually good performance is the dedicated heat input provided to the monitor.

'The monitor is held in the header encapsulant (refer to Figure 1). A thin insulator and a heat pellet are placed between the potting and a Min-K insulator. A hole in the insulator exposes the monitor to the heat pellet. 'Two disks of $\mathrm{Zr} / \mathrm{BaCrO}_{4}$ are placed in this cavity in the insulator. 'This provides a consistent, large heat input to the monitor. However, this same scheme is 1. ad in other batteries with disappointing results. It is not clear why the monitor works in this application but not in other similar applications.

Therefore, a stick-on temporature indicator is attached to the side of the battery to give further assurance that a discharged battery will not be used in a flight unit. 'This indicator changes from white to black at about $90^{\circ} \mathrm{C}$. 'This was added to the battery late in development because of the erratic history of the $4 \mathrm{~B}^{\prime} \mathrm{T} R \mathrm{R}$ monitor.

\section{Unique Characteristics}

This battery has three unique features. First, it is the only thermal battery that holds the percussion primer in its header. Other primer-fired batteries, such as the MC:3246 ${ }^{6}$ and the MC3929, hold the primer in the opposite end of the battery from the header second, it is the only thermal hattery in production with a hermetically sealed primer interface (the MC3246A will go into production in late 1989 and it will have a similar interface). Third, it is the only battery that has a separate reliability speci. fication for its monitor.

The primer had to be in the header because the base end of the battery rests on a flat surface. 'Thus, the free end of the battery, the header, must be used for both the output terminals and the actuator input. Other primer activated thermal hatteries either have threaded hoies (not through holes) in a thick plate that also folds the primer, or they have a circumferential mounting feature (e.g., a bracket attached to the side of the battery).

The primer interface was hermetically sealed by laser-welding a $0.13-\mathrm{mm}$-thick stainless-steel disk over the primer cavity after the primer was inserted. Testing done by Nick Durand, Division 2512, showed that the all-fire velocity of the firing pin was not changed by the addition of this disk. ${ }^{7}$ The monitor has its own reliability specification because it is much less reliable than the battery, and it was not practical to jeopardize the acceptance of the battery based on the unreliability of the monitor. 'This decision was justified by the next assembly use of the monitor: it is checked only before the battery and actuator are assembled into a telemetry unit at Allied-Signal, Kansas City Division. 'Thus, the probability of the battery's being accidently activated was so small that a lower reliability for the monitor was acceptable. 


\section{Development}

The MC3714 program was started and stopped on several occasions. 'The last restart of the MC3714 program was in early 1986. The hattery had 15 cells and an unlithiated cathode at that time. 'The battery stack is shown in Figure 5 .

Even though these units had a center hole, fuse strips were used to ensure that all heat pellets were ignited. 'The insurance was needed because the M42C: Primer could not reliably ignite all the heat pellets. However, it created a potential failure mode. If the primer innited all the heat pellets, then the fuse strips could cause overheating of the cells by adding heat to an already hot area. The fuse strips were eliminated after the WW42C1 Primer replaced the M42( $x$,

Since the operating life was inadequate and the voltage vs. time curve could not be flattened by using a better insulating wrap, one cell was added to the battery. This extended the battery life by raising the voltage vs, time curve. At the same time, the cathode was changed to the (then) new lithiated material, which eliminated the initial voltage transient inherent in $\mathrm{FeS}_{2}$ cathodes and produced a more consistent end of life. However, failures were still common, even after this change was made.
'The fuilures were all the result of poor thermal management. 'The next change was designed to correct this problem. A $0.76-\mathrm{mm}$-thick Fiberfrax insulator was placed between the adjacent heat pellets at both ends of the stack. 'This new stack configuration is shown in Figure 6.

There were still failures after this change, but they were less frequent. In addition, battery performance, as measured by active life and the voltage at $146 \mathrm{~s}$, was improved. Postmortem examination of the failed batteries showed that overheating was still a problem and it seemed to be focused on the inside diameter of the most negative anode.

'The inside diameter (ID) of the encapsulant was decreased once to ensure that all the heat pellets would be ignited. I ater, it was increased to its original size because it was evident that the primer could reliably activate the battery. It was thought at that time that decreasing the encapsulant II) had contributed to the battery noise and anode damage. It was also thought that the heat from the primer was the cause of the anode damage. Both of these concepts were later proved incorrect.

At the end of development, the anode damage was thought to be under control hecause no batteries had noise after the last design change, which increased the encapsulant. II). 


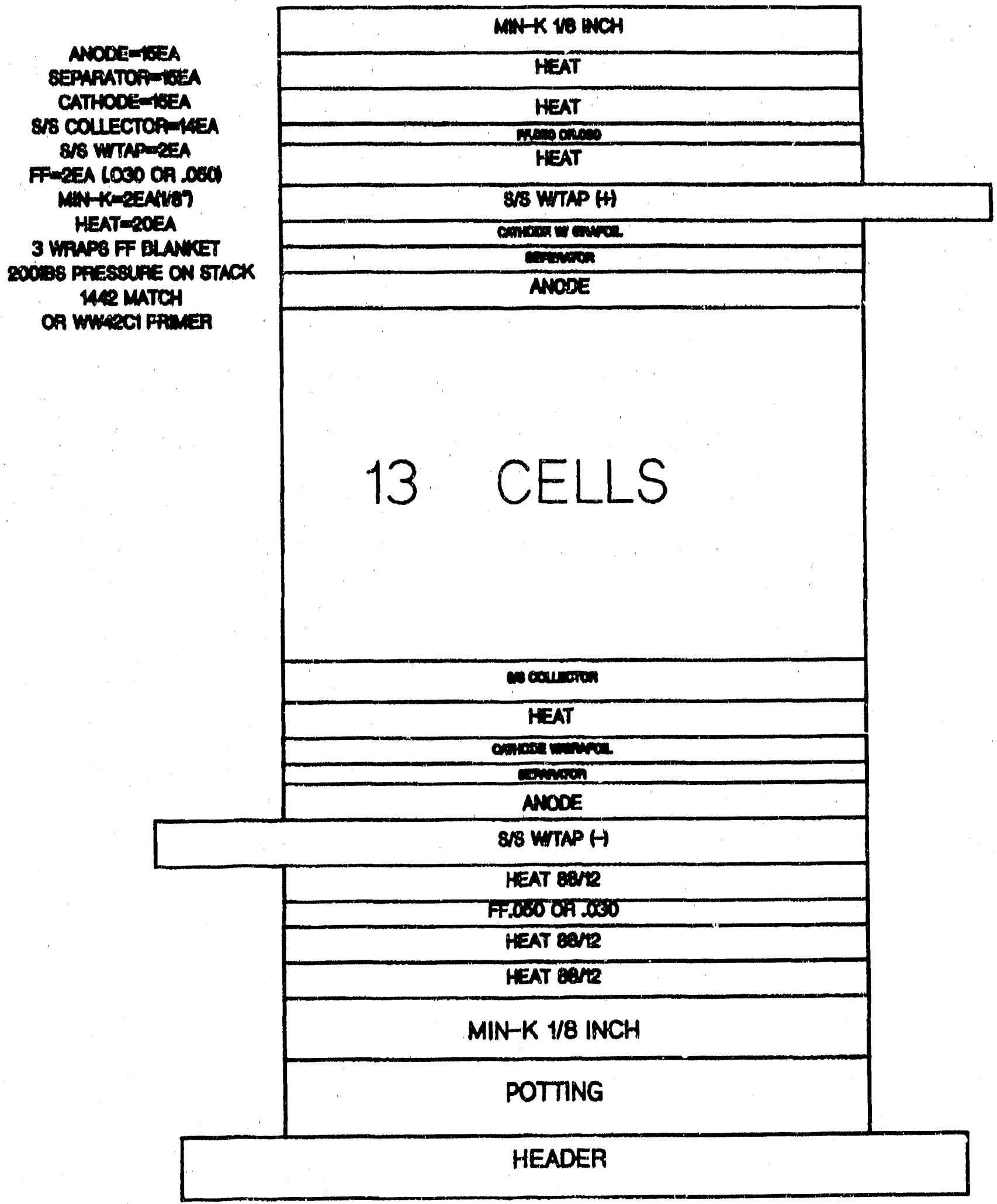

Figure 5. M(3714 Initial Battery Sitack Assembly 


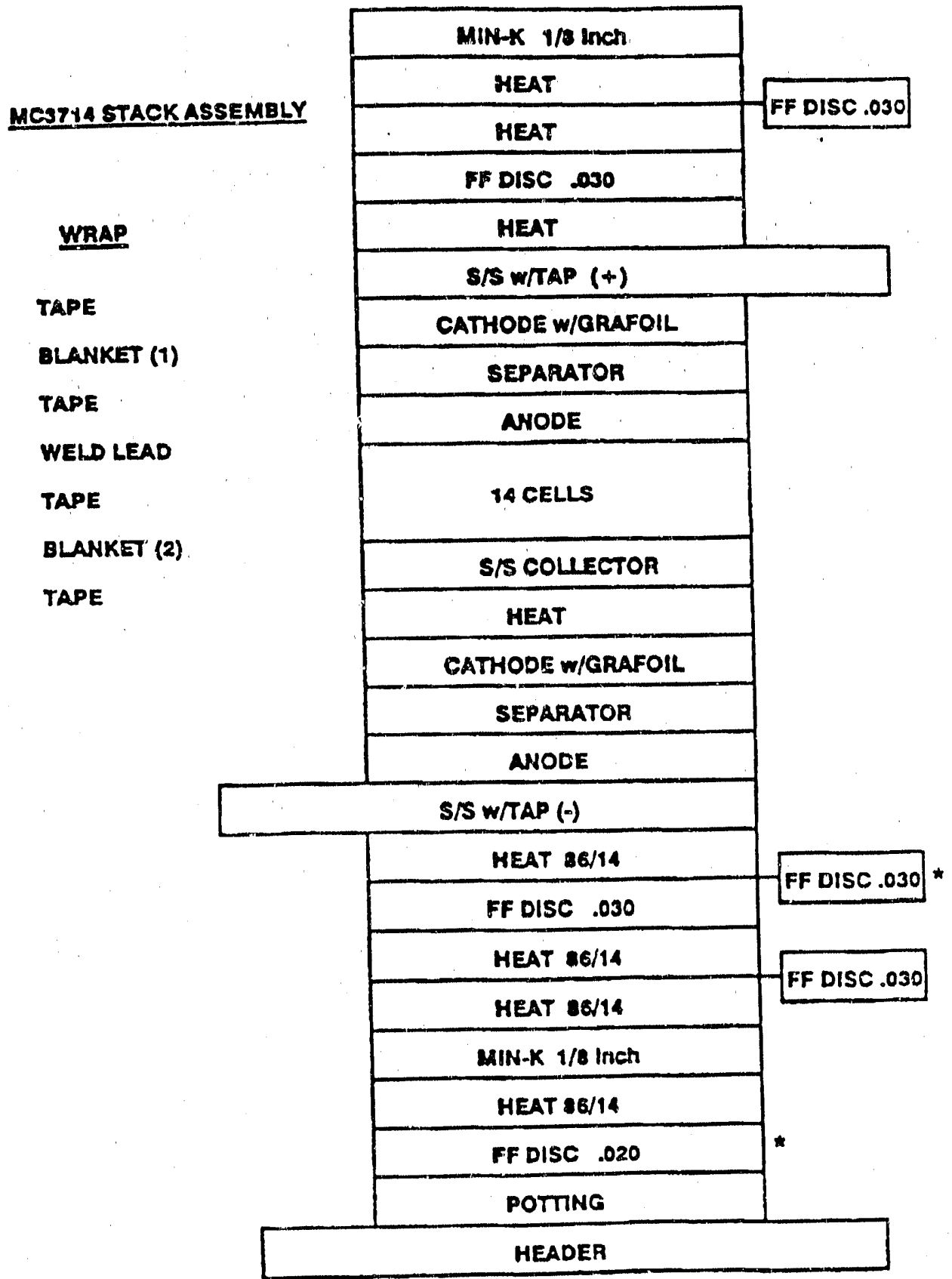

- DESIGN CHANGE

Figure 6. Stack With Separation of Double Heat Pellets (continued on next page) 


\begin{tabular}{|c|}
\hline BASE \\
\hline MIN-K V8 INCH \\
\hline HEAT \\
\hline FF (030) \\
\hline HEAT $86 / 44$ \\
\hline FF (030) \\
\hline HEAT $86 / 44$ \\
\hline S/S W/TAB $(+)$ \\
\hline
\end{tabular}

16 CE:LS

\begin{tabular}{|c|}
\hline S/S W/TAB (-) \\
\hline HEAT $86 / 14$ \\
\hline FF (O30) \\
\hline HEAT \\
\hline FF (030) \\
\hline HEAT $86 / 14$ \\
\hline MIN-K DISC $1 / 8$ INCH \\
\hline HEAT $86 / 14$ \\
\hline FF DISC 1030$)$ \\
\hline POTTING \\
\hline HEADER \\
\hline
\end{tabular}

Figure 6. (concluded)

\section{Heat Balancing}

The heat balance is normally specified by dividing the total calorific input of one heat pellet by the total weight of one cell. The heat balance is unique for every therma! battery. It is determined experimentally through an iterative process. The optimum heat balance for the MC3714 was determined to be 100 $\mathrm{cal} /$ (g-cell). This corresponds to a heat pellet weight of $0.93 \mathrm{~g}$ using the $86 / 14\left(86^{\circ}, \mathrm{Fe}, 14 \%, \mathrm{KClO}_{4}\right)$ heat powder. This heat powder has a calorific output of $260 \mathrm{cal} / \mathrm{g}$. 


\section{Environmental Testing}

The only active test environment was spin. This was dictated by CD239294. Flight test results were used to qualify the design to its use environment, since the use environments were too extreme to simulate in a laboratory

\section{Aging Test}

Eight batteries were built with a separator containing $4 \%$ LiO (Ref. 8 ) to simulate 25 years of aging. These "aged" batteries performed as well as the "unaged" batteries. These batteries were tes'ed on the GEND spin tester. The data for this test are shown in Table 3.

\section{GEND Development}

GEND development activities started in October 1985. All the various configurations of the battery were constructed and tested at. GEND. In addition, many of the SNL batteries were tested at GEN!) because GEND had the only acceptable spin tester.

The reliable operation of the spin tester was critical to the success of this program.

All the (XENI) development test data are in the Department $2520 \mathrm{HP} 3000$ database sye $\mathrm{em}^{\mathrm{m}}$. The data were also transmitted into the Product Test Data (PTD) system maintained by Department 2820. The GEND data presented at the Producibility Design Review will be shown here. All the GEND bat teries were tested in the spin environment.

The Producibility Design Review was held on June 24, 1988. At this meeting, GEND presented data showing pellet yields ('Table 4), a slatistical summary of battery performance (Table 5), and a battery cost. estimate (Table 6). The cost data are based on a total build of 139 batteries, which will yield 29 deliverable batteries. These data are shown in the tables that follow. The producibility assessment was also presented. The battery was given a producibility assessment of "A" by GEND. This assessment means the battery can be produced with existing equipment and techniques and is expected to meet its requirements easily.

\section{Table 3. SNL Aging Test Data}

\begin{tabular}{cccccc}
$\begin{array}{c}\text { Serial } \\
\begin{array}{c}\text { Num- } \\
\text { ber }\end{array}\end{array}$ & $\begin{array}{c}\text { Test } \\
\text { T'emp. } \\
\left({ }^{\circ} \mathrm{C}\right)\end{array}$ & $\begin{array}{c}\text { Rise } \\
\text { Time } \\
(\mathrm{V})\end{array}$ & $\begin{array}{c}\text { Peak } \\
\text { Voltage } \\
(\mathrm{V})\end{array}$ & $\begin{array}{c}\text { Voltage } \\
\text { at Life } \\
(\mathrm{V})\end{array}$ & $\begin{array}{c}\text { Active } \\
\text { Life } \\
(\mathrm{s})\end{array}$ \\
\hline $\begin{array}{c}\text { (Spec.) } \\
146\end{array}$ & 54 & 140 & 30.84 & 29.17 & 333 \\
148 & 54 & 152 & 29.43 & 27.19 & 308 \\
149 & 54 & 140 & 30.79 & 29.16 & 332 \\
150 & 54 & 150 & 30.76 & 28.84 & 312 \\
144 & -40 & 225 & 28.97 & 26.99 & 204 \\
145 & -40 & 182 & 29.87 & 27.38 & 197 \\
147 & -40 & 178 & 30.03 & 27.93 & 220 \\
151 & -40 & 200 & 29.77 & 27.33 & 197 \\
\hline
\end{tabular}

Tabie 4. GEND Development Pellet Yields

\begin{tabular}{lccc} 
Pellet & Accepted & Rejected & $\begin{array}{c}\text { Yield } \\
\text { ("i) }\end{array}$ \\
\hline Anode & 1198 & 291 & 80.4 \\
Separator & 1645 & 91 & 94.7 \\
Cathode & 1418 & 82 & 94.5 \\
Heat & 1075 & 14 & 98.7 \\
\hline
\end{tabular}


Table 5. GEND Development Performance Summary

\begin{tabular}{|c|c|c|c|c|c|c|}
\hline & Required & Minimum & Mean & Maximum & Sigma & K-factor \\
\hline \multicolumn{7}{|l|}{$-40^{\circ} \mathrm{C}: 21$ units } \\
\hline Rise time (ms) & 500 & 168 & 177 & 190 & 6.73 & 47.9 \\
\hline Peak voltage (V) 32.0 & 29.9 & 30.1 & 30.9 & 0.25 & 7.8 & - \\
\hline Voltage at $146 \mathrm{~s}(\mathrm{~V})$ & 24.0 & 26.9 & 27.4 & 27.9 & 0.3 & 11.8 \\
\hline Time above $24.0 \mathrm{~V}(\mathrm{~s})$ & 146 & 181 & 197 & $: 17$ & 11.8 & 4.4 \\
\hline \multicolumn{7}{|l|}{$54^{\circ} \mathrm{C}: 28$ units } \\
\hline Rise time (ms) & 500 & 124 & 136 & 150 & 6.2 & 58.99 \\
\hline Peak voltage (V) 32.0 & 30.0 & 30.8 & 31.1 & 0.2 & 5.68 & - \\
\hline Voltage at $146 \mathrm{~s}(\mathrm{~V})$ & 24.0 & 26,2 & 28.3 & 28.8 & 0.6 & 7.4 \\
\hline Time above $24.0 \mathrm{~V}(\mathrm{~s})$ & 146 & 195 & 269 & 300 & 20.9 & 5.9 \\
\hline
\end{tabular}

Table 6. Estimated Cost of Lot 1 Batteries

Cost Element

Material

Total cost (\$)

Labor

24,852

Direct support

48,612

24,306

Lot Cost

97,771

\section{Product Characteristics}

This battery conforms to the thermal battery design guide (DG10177, Issue B) except the battery is

not manufactured with a constant displacement of the stack.

\section{Component Parts}

The component parts are summarized in Table 7. This table lists the principal dimensions and drawing control number for all the parts that make up the MC3714. 


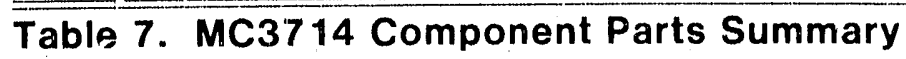

\begin{tabular}{|c|c|c|c|c|c|c|}
\hline $\begin{array}{c}\text { Component } \\
\text { Part } \\
\end{array}$ & $\begin{array}{c}\text { Drawing } \\
\text { No. }\end{array}$ & $\begin{array}{c}\text { Diameter } \\
(\mathrm{mm})\end{array}$ & $\begin{array}{c}\text { Thickness } \\
(\mathrm{mm})\end{array}$ & $\begin{array}{c}\text { Weight } \\
\text { (g) }\end{array}$ & $\begin{array}{l}\text { Number } \\
\text { Required }\end{array}$ & $\begin{array}{c}\text { Total Weight } \\
(\mathrm{g})\end{array}$ \\
\hline Base & $349530-200$ & 38.10 & 3.17 & 24.1 & 1 & 24.1 \\
\hline Case & $324410-207$ & 38.10 & 0.508 & 24.0 & 1 & 24.0 \\
\hline Anit-spin ring & $380610-200$ & 38.10 & 5.50 & 15.67 & 1 & 15.67 \\
\hline $\begin{array}{l}\text { Header } \\
\text { encapsulated }\end{array}$ & $349522-200$ & 38.10 & 8.26 & 40.9 & 1 & 40.9 \\
\hline $\begin{array}{l}\text { Header } \\
\text { insulator }\end{array}$ & $384053-200$ & 25.40 & 1.27 & 0.27 & 1 & 0.27 \\
\hline Heat & $349548-200$ & 25.40 & 0.448 & 0.93 & 22 & 24.2 \\
\hline Anode & $349546-200$ & 25.40 & 0.35 & 0.19 & 16 & 4.76 \\
\hline Separator & $349545-200$ & 25.40 & 0.296 & 0.264 & 16 & 7.38 \\
\hline Cathode & $349544-200$ & 25.40 & 0.33 & 0.563 & 16 & 9.57 \\
\hline Grafoil & $349545-200$ & 25.40 & NA & NA & 16 & 0.10 \\
\hline Collector & $370512-200$ & 25.40 & 0.127 & 0.48 & 15 & 12.64 \\
\hline Collector w/lead & $370511-200$ & 25.40 & 0.127 & 0.57 & 2 & 1.76 \\
\hline \multirow[t]{2}{*}{ Shim } & $332807-202$ & 36 & NA & NA & $\mathrm{AR}$ & 0.43 \\
\hline & & $\begin{array}{l}\text { Length } \\
\text { (mm) }\end{array}$ & & $\begin{array}{l}\text { Width } \\
(\mathrm{mm})\end{array}$ & & \\
\hline Insulation wrap & $370611-200$ & 114 & 20.32 & 35.5 & 1 & 2.3 \\
\hline Insulation wrap & $370612-201$ & 114 & 20.32 & 35.5 & 1 & 4.7 \\
\hline
\end{tabular}




\section{Assembly}

'To begin the stack assembly, an encapsulated MC3714 header is inverted and placed on a stacking fixture. The battery components are then stacked on to the inverted header as specified in the Stack Assembly Drawing (349542) (Figure 6).

The battery stack is then placed on the press. The stack should be straightened before any load is put on it. A ram with the same diameter as the nominal pellet diameter is used to load the stack. 'The stack force should be maintained at $890 \pm 225 \mathrm{~N}$ until the battery is wrapped.

The battery is first wrapped with glass tape. Then a 2 -mm-thick Fiberfrax blanket is wrapped around the battery. Another glass-tape wrap is applied. The stack leads are then resistance-welded to the appropriate leads from the header. A strip of mica is placed between the welded leads and the blanket. Another glass-tape wrap is applied, and two layers of the $2-\mathrm{mm}$ Fiberfrax blanket are wrapped around the stack. A final glass-tape wrap is applied. The completed stack assembly is placed into a case assembly, and the header is welded to the case to complete the assembly of the MC37.14.

\section{Battery Temperatures}

To record the external temperatures of the battery, thermocouples were attached to the outside of the battery at the locations shown in Figure 7 . The data recorded are shown in Figure 8.

All temperature data were recorded at $1 \mathrm{~s}$ intervals using an HP3852 Data Aquisition/Control Unit controlled by an HP150 Personal Computer. 'Type " $K$ " thermocouples were used for all tests. These test.s were not performed in a spin environment because that capability did not exist.

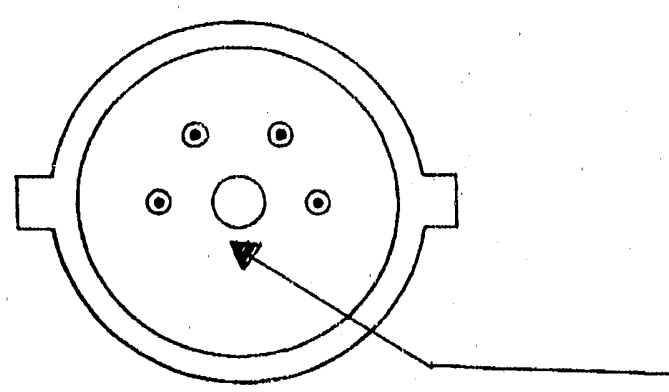

HEADER

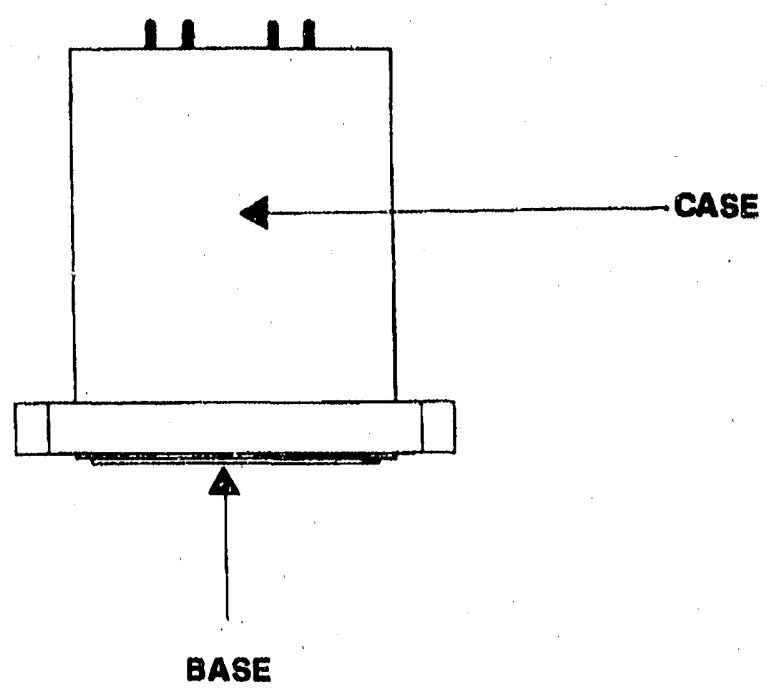

Figure 7. External Thermocouple Locations 

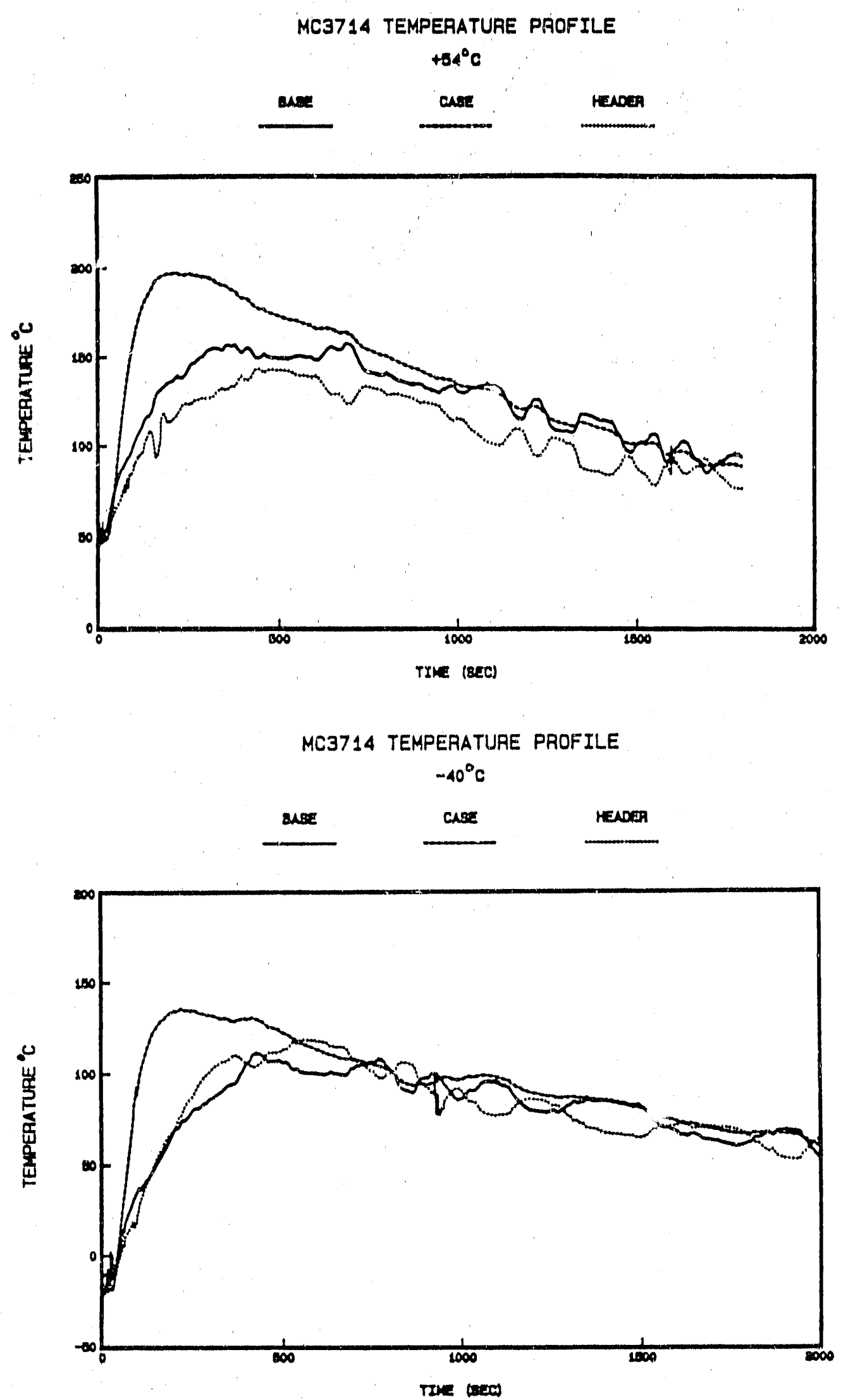

Figure 8. External Temperatures During Discharge 


\section{Performance Characterization}

The discharge load for the MC3714 is $500 \mathrm{~mA}$ constant current. To characterize the MC3\%1.4 dis. charge capability, one battery was discharged at each temperature $\left(-40^{\circ} \mathrm{C}\right.$ or $\left.54^{\circ} \mathrm{C}\right)$ at the following con. stant current loads: $250 \mathrm{~mA}, 1 \mathrm{~A}, 2 \mathrm{~A}$. 'T'wo opencircuit tests were also performed. The data for these tests are shown in Figures 9a-9e.

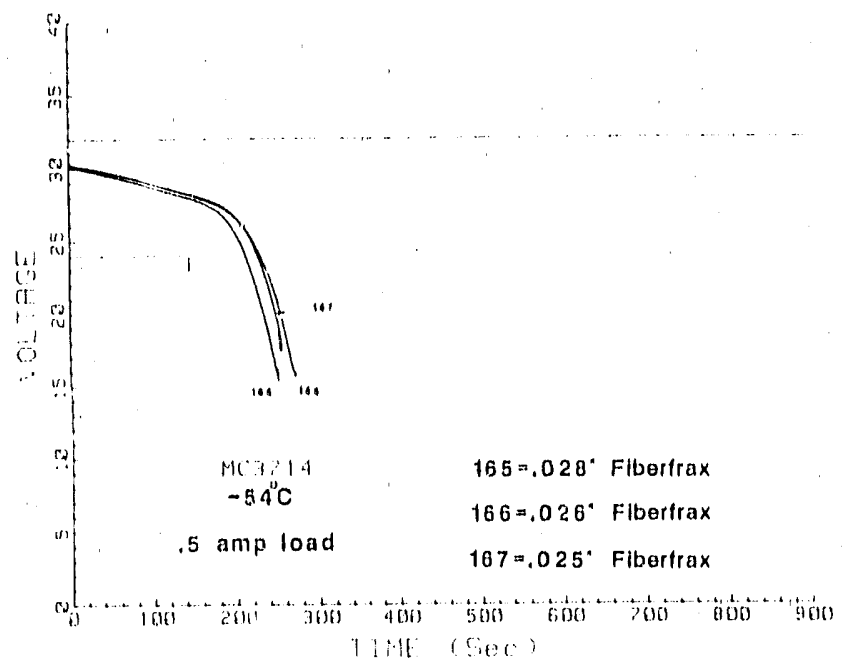

(a) MC3714 at $-54^{\circ} \mathrm{C}, 0.5-\mathrm{A}$ load

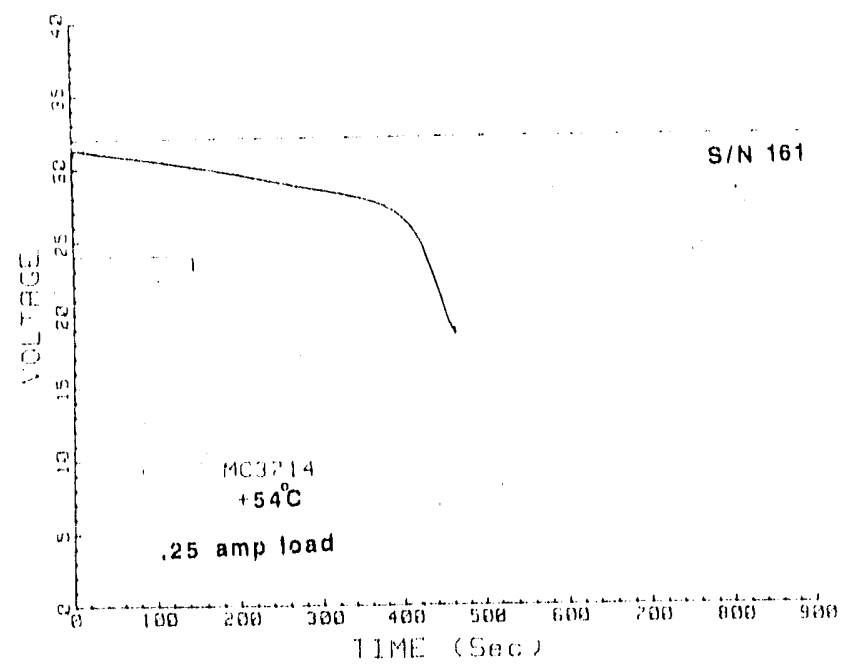

(b) $\mathrm{MC} 8714$ at $+54^{\circ} \mathrm{C}, 0.25-\mathrm{A}$ load

Figure 9. Performance at Various Loads

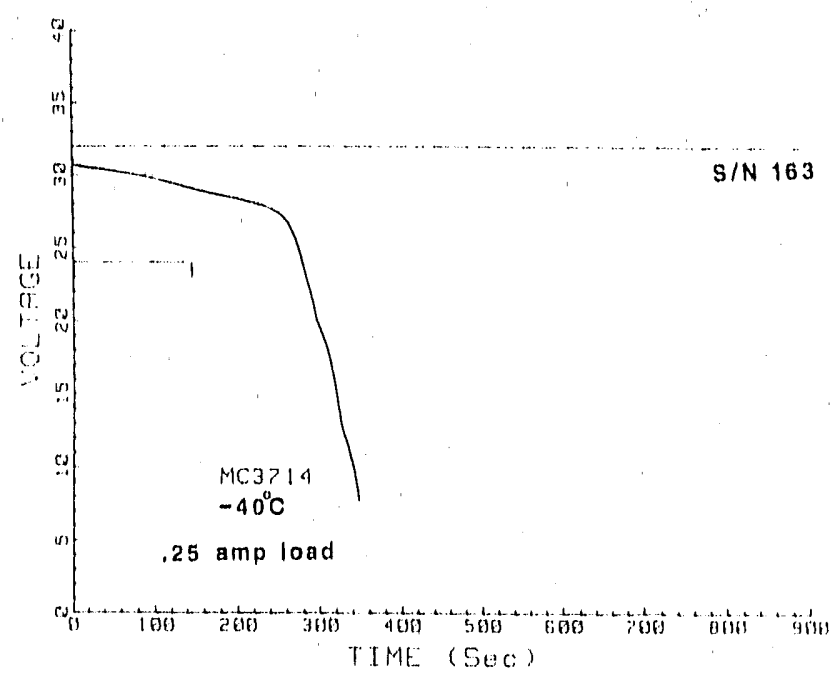

(c) MC3714 at $-40^{\circ} \mathrm{C}, 0.25-\mathrm{A}$ load

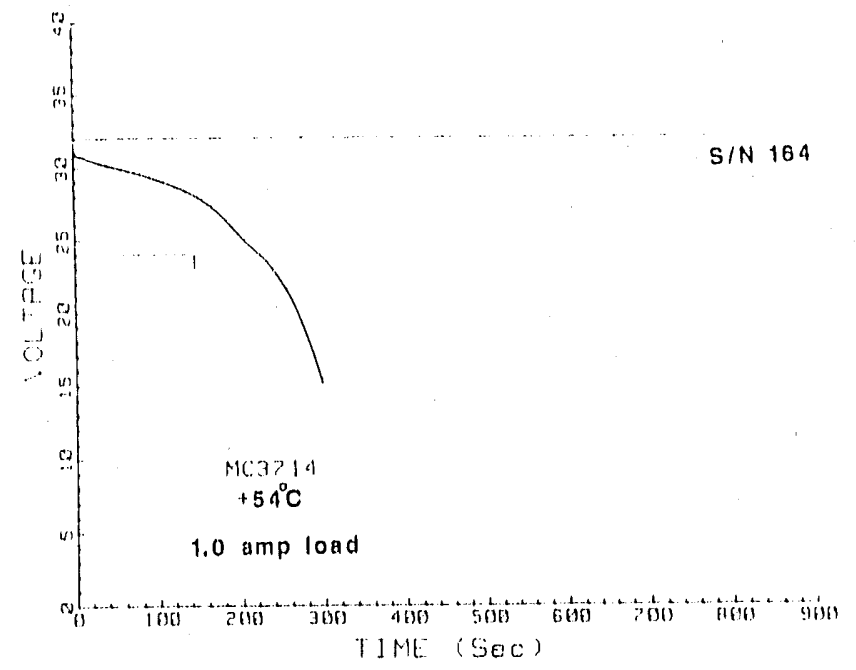

(d) $\mathrm{MC} 3714$ at $+54^{\circ} \mathrm{C}, 1.0$ - A load

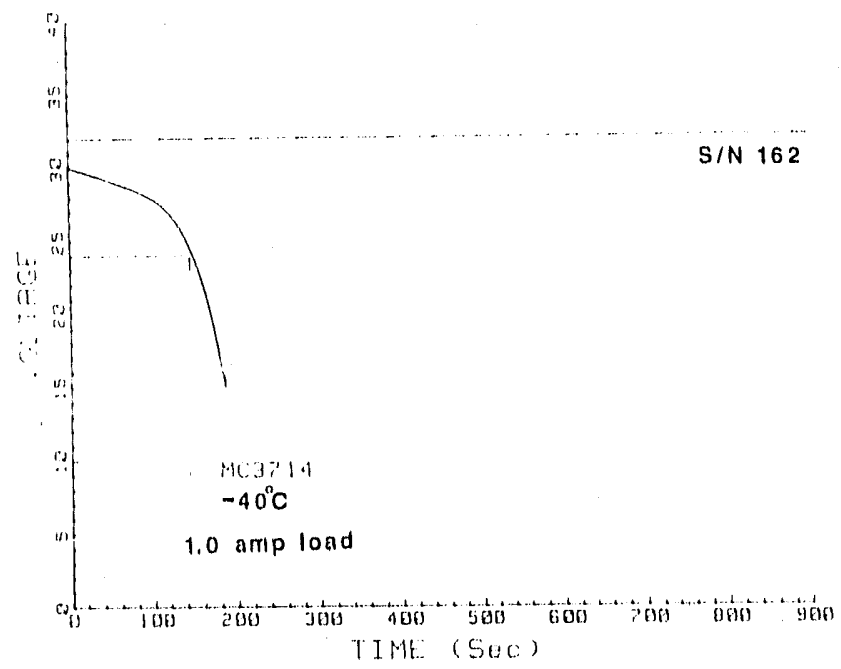

(e) MC 3714 at $-48^{\circ} \mathrm{C}, 1,0-\mathrm{A}$ load 


\section{Mass Properties}

'The center of' gravity and moment of inertia for each of the three major axes were determined using expended batteries. The axes and datums used are shown in Figure 10. The m is properties data are listed in Table 8 . These data were generated by the Rotational Dynamics Division (Division 7543).

MASS PROPERTIES REFURT

Test Them Description _.......MG3214t

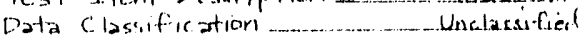

Test Date(s) LL/10/89.....

Weight:

Weignt $=-36.5-16 \mathrm{~s}$

Center of Garaty (Ci)

$x=-244$ in

$y=\ldots .7 .57 \ldots$ in

$z=-751$ in

Moment of Inertia (MOI)

$T K X=1 \ldots .113 \ldots$ ib $\mathrm{in}^{2}$

$I Y Y=-243-16 \mathrm{in}^{2}$

$I Z Z=-232-15 \cdot 1 \mathrm{in}^{2}$
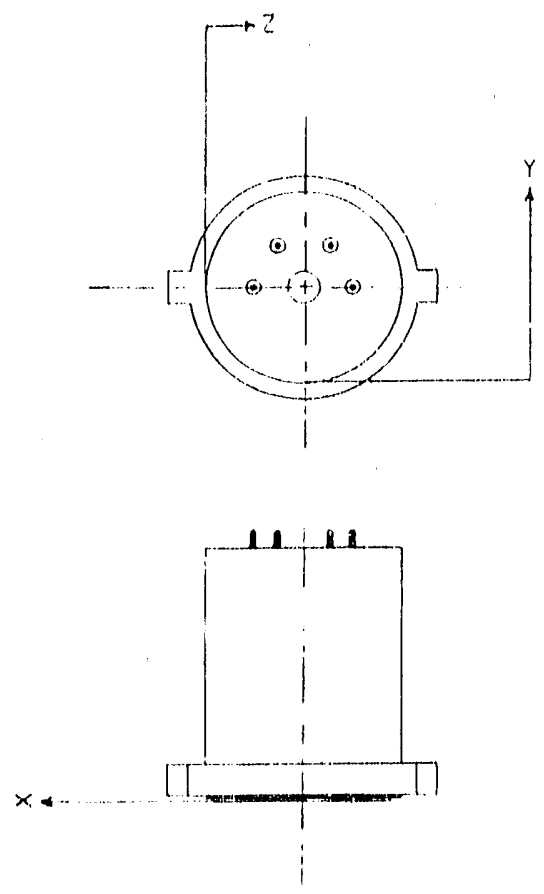

Daturn (s)

Figure 10. Axes and Datums for Mass Properties:
Table 8. MC3714 Mass Properíles

\begin{tabular}{cccc}
\multicolumn{2}{c}{ Conter of Gravity } \\
Axis & $\begin{array}{c}\text { Location } \\
(\mathrm{cm})\end{array}$ & Axis & $\frac{\text { Moment of Inertia }}{\left(\mathrm{g}-\mathrm{cm}^{2}\right)}$ \\
\hline $\mathrm{X}$ & 1.880 & $\mathrm{XX}$ & 632.6 \\
$\mathrm{X}$ & 1.875 & $\mathrm{YY}$ & 635.6 \\
7 & 2.512 & $\mathrm{ZZ}$ & 295.8 \\
\hline
\end{tabular}

\section{Production History}

'This battery went into production in late Septennher 1988. A 'TMS was conducted the week of October 17,1988 . During the testing for the 'TMS, a voltage dropout ocourred on a battery tested at $54^{\circ} \mathrm{C}$. Postmortem of the hattery showed that the first cell (i.e., the most negative anode) overheated. Electrolyte from the first cell leached through the insulating wrap and briefly shorted to the positive power lead. The short occurred 5 s into the discharge and lasted about 3 ins. An evaluation program was immediately begun to determine what deaign change could ellminate the uverheating that was observed.

\section{Lot 1 Design Change}

It was sbvious that there was an excessive heat transient that resultod in either moderate damage to the first cell, gross ctaniage to the first cell accompanieli by vritage perturbations (i.e., "noise"), or failure of the battery. 'The moderate damage is illustrated in Pigure 11. The grosis damage is illustrated in Figure 12. It was also obvious that the hent transient was not grossly excessive for the following reasons: First, hatteries tested cold (i.e., at $-40^{\circ} \mathrm{C}$ ) showed minorto-moderate damage to the first anode only. There were never any voltage perturbations, gross damage 10 the anode, or failure of batteries. Second, the gross rlanage and associated noise oocuired on only $10^{\circ} \%$, of the batteries tested hot, (i.e., $\left.54^{\circ} \mathrm{C}\right)$. There were no lailures in this design configuration until the TMS.

Since the noise was infrequent, it was lelieved that the heat managernent in the battery was marrimal a $54^{\circ} \mathrm{C}$ and that variations in the primer output. accomted for variations in the occurrence of noise. 'Ihis belief determined the approach that would be taken to solve the battery overheating problem.

The design evaluation program hegan by building batteries with minor design changes that attempted 


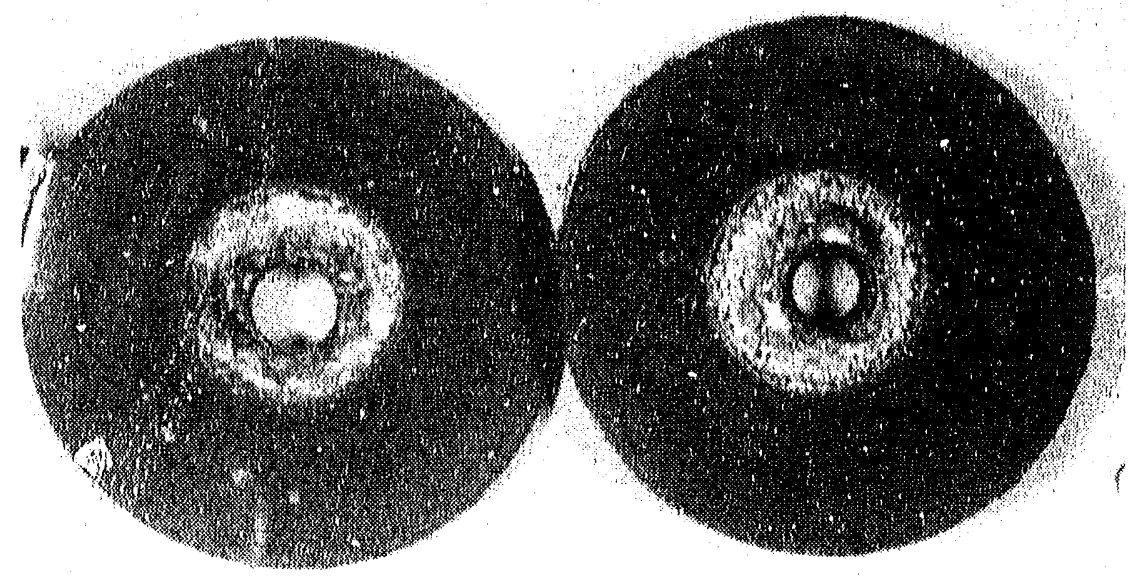

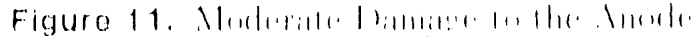

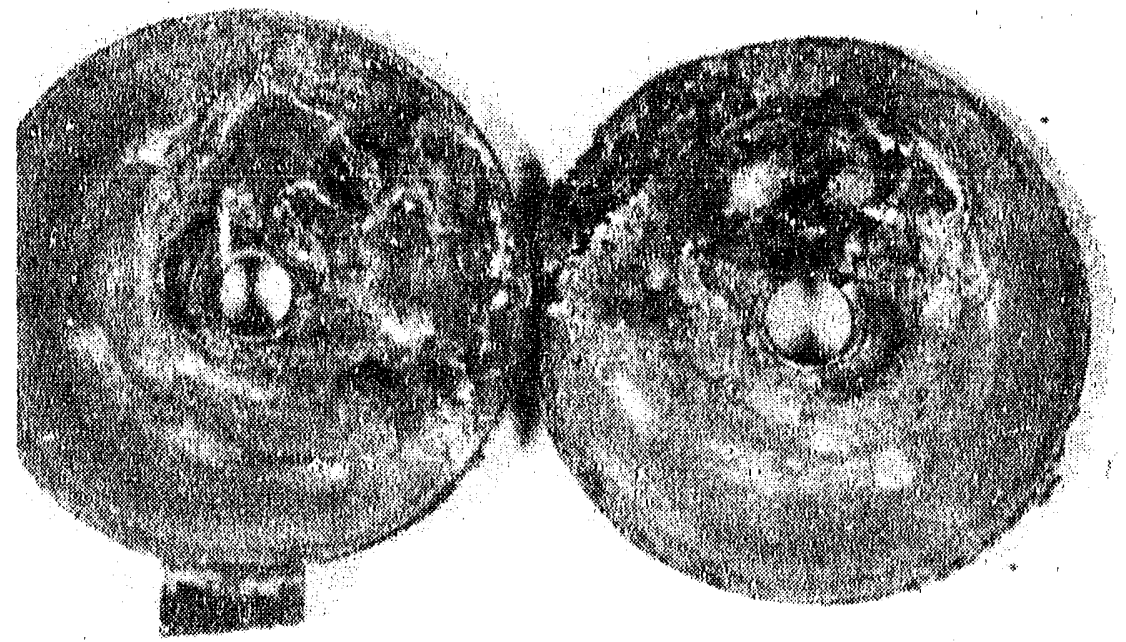

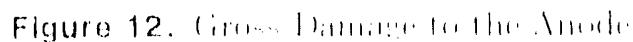


to moderate the primer oulput. One modification was to enlarge the inside diameter of the Min-K insulatur at the header end of the stack. 'The idea was to trap a portion of the primer output in the Min-K cavity and effectively roduce the output of the primer. "Ithls change had no effect on the overheuting protlem. Another modilication was to pull a current collectors with a small II) $(-3 \mathrm{~mm})$ in the stack (lose to the primer. 'l'his was annther altempt to effoctively re. duce the cutpul of the primer. 'This atser hed no eflect on the overheuting problom.

Another approach was to implement a modification that had proved succenstul on another program. An additional current collector was used on the litrst. anode as a heatsink. This sliminated the overhenting problem: the first anode from a hot batery losiked like the flrst anode from a cold battery. However, the heatsinking proved excessive when this design was tested at low tamporature; two units failed the activated life requirement.

'The next idea was to invert the batlery stack. This resulted in the most negative anchle's being at the base and of the battery anstead of at the heador end. Bateries tested this way had the samo damage to the most negalive anode as noninverted battories. 'This showed that the overheating was caused by the heat transfer irom the "dummy cells" (i.e., the heat pellets and insulation between the stack and the header). This test dofined the souree of the problem.

'The only question remaining was whother the overhealing was craused by an excessive amount of hent transfer or un excessive rate of hent transfor from the buffer area to the first cell. Sinco the most positive anode was exposed to approximately the same heat input as the most negative anocle without visible damage, it was conctuded that the hent transfer rate was excessive. 'The heat trander rate to the most positive anode was moderated by both the masses of the cathode and separator pollets and the thermal eapacitance of the separator pellet. (which goes through a phane chango), Since a capacitive element, the extra oolleotion, had already been tried without. success, a resistive olement, an extra liberfrax insulator, was chesen to reduce the heat transfer rate from the buffer area lo the most negative anode.

An additional Fiberima insulator was placed beIworen the "dummy cell" heat pellets and the battery utack (Figure 6). 'This elimlnated tho overhenting problem and made the battary performance more comslstent.

\section{Production Summary}

The fir'st production lot of the MC:371.4 was complete as of' danuary 1989. 'This lot was buil at. (itND) in December 1988 and danuary lo89) Table? showe the lot build stmmary. There was only one reject, a build error, and this was lested an a daily lot sample unit. "This resulted in a $100^{\prime \prime}$ ". vield for the lot. the daily lot sample porformarce data are summarized in 'Table 10 and the re-l'M's clata are listed in 'Table 11.

The life of program build for the MCs3714 is presently scheduled to be 1.44 delivered units.

\section{Table 9. Lot 1 Production Summary}

\begin{tabular}{lc} 
'I'otal Fabricated & 100 \\
\hline Preproduction/l'Ms & 28 \\
Daily Lot Samples & 50 \\
Wh & 25 \\
Rejects & 1 \\
$\quad 1$ stack error (used as lot sample) & \\
lot Yield & $1000^{\prime \prime}$
\end{tabular}


Table 10. Lot 1 Performance Summary

\begin{tabular}{|c|c|c|c|c|c|c|}
\hline & Required & Minimum & Moan & Maximum & Sigma & K-factor \\
\hline \multicolumn{7}{|l|}{$-34^{\circ} \mathrm{C}: 25$ units } \\
\hline Rise time $(\mathrm{ms})$ & $5(1) 0$ & 150 & 167 & 200 & 9.70 & 34.31 \\
\hline Poak vollage (V) & i32.0 & $20.8(1)$ & 30.14 & 31.26 & 0.07 & 25.433 \\
\hline Voltage at $146 \mathrm{~s}(\mathrm{~V})$ & 24.0 & 26.96 & 27.86 & 27.57 & 0.15 & 21.92 \\
\hline 'Time above $24.0 \mathrm{~V}(\mathrm{~s})$ & 146 & 195.5 & 218.6 & 236.5 & 9.50 & 7.64 \\
\hline \multicolumn{7}{|l|}{$60^{\circ} \mathrm{C}: 25$ units } \\
\hline Rlse time (ms) & $6(1) 0$ & 120 & 131 & 140 & 6.85 & 53.81 \\
\hline Peak voltarre (V) & 32.0 & $3(1,55$ & 30.69 & 30.78 & 0.06 & 22.97 \\
\hline Voltage at 146 \& (V) & 24.1 & 27.90 & 28.18 & 28.36 & ().12 & 33.71 \\
\hline Time above $24.0 \mathrm{~V}(\mathrm{~s})$ & 146 & 284.0 & 302,42 & 319.2 & 9.19 & 17.01 \\
\hline
\end{tabular}

Table 11. Lot 1 Re-TMS Data

\begin{tabular}{|c|c|c|c|c|c|}
\hline $\begin{array}{c}\text { Serial } \\
\text { Number }\end{array}$ & $\begin{array}{l}\text { T'est } \\
\text { l'emp. } \\
{ }^{\circ}(\mathrm{c})\end{array}$ & $\begin{array}{l}\text { Rise } \\
\text { 'T'ime lo } \\
24 \mathrm{~V}\end{array}$ & $\begin{array}{c}\text { Perk } \\
\text { Voltuge }\end{array}$ & $\begin{array}{l}\text { Voltage } \\
\text { at } 146 \mathrm{~s}\end{array}$ & $\begin{array}{c}\text { Time Above } \\
24 \mathrm{~V}\end{array}$ \\
\hline 113 & $-\ldots 40$ & 180 & 30.12 & 27.31 & 210.3 \\
\hline 115 & $\ldots 40$ & 170 & $3(1,01$ & 27.36 & 215.2 \\
\hline 116 & $\ldots 40$ & 190 & 30.06 & 27.31 & 206.9 \\
\hline 120 & $\ldots d 0$ & 180 & 29.94 & 27.23 & 204.1 \\
\hline $12 !$ & $\ldots .10$ & 180 & 29.99 & 27.25 & 208.9 \\
\hline 112 & 54 & 140 & 30.56 & 28.21 & 305.2 \\
\hline 114 & 5.1 & 14() & 30.62 & 28.20 & 308.3 \\
\hline 117 & 54 & 140 & 80.61 & 27.87 & 286.13 \\
\hline 119 & 54 & $14 i i$ & 30.60 & 28.12 & 299.1 \\
\hline 121 & 54 & 1330 & 30.54 & 28.01 & 288.0 \\
\hline 123 & 5.4 & 130 & 30.58 & 28.04 & 289.2 \\
\hline
\end{tabular}



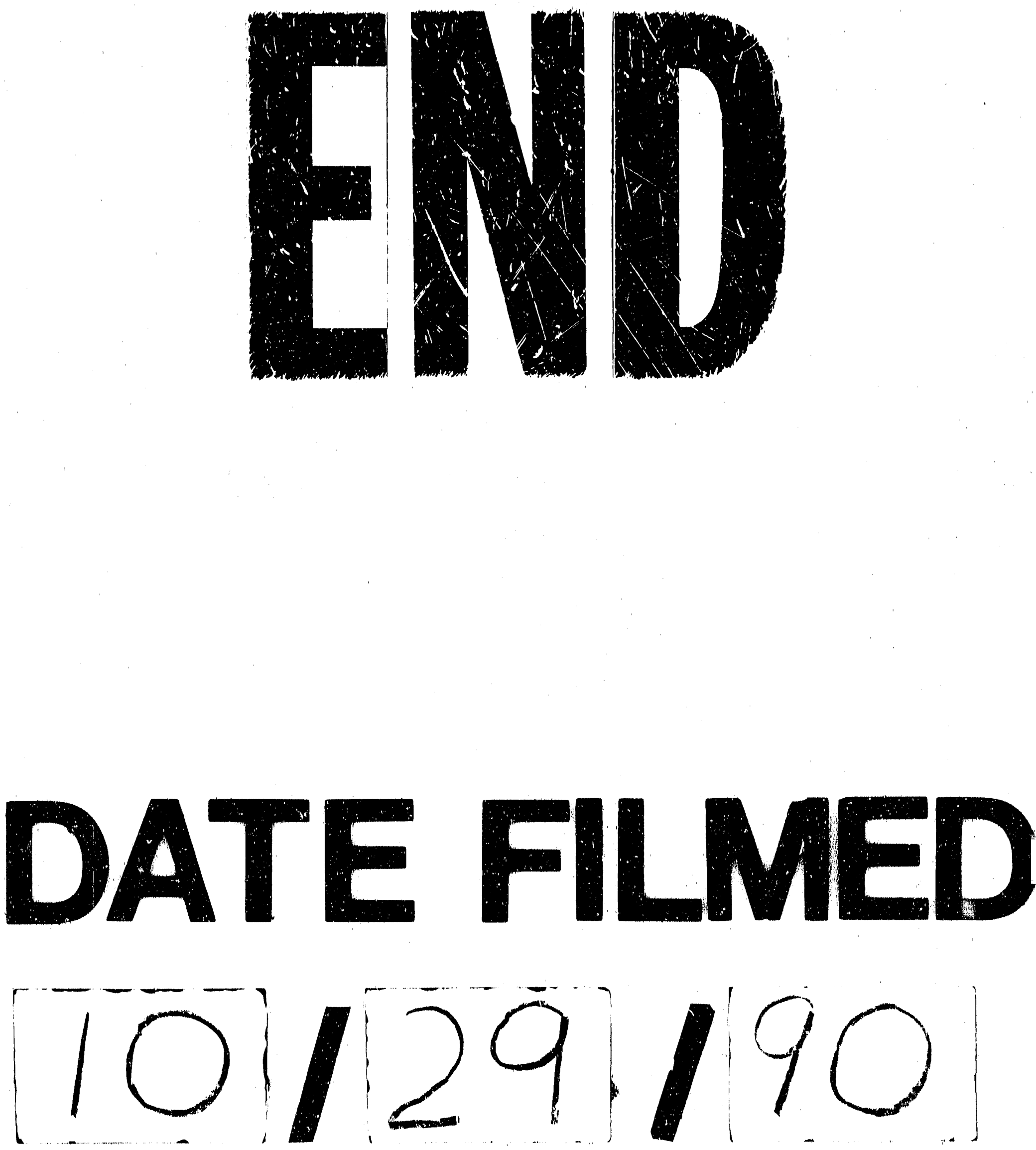
